\title{
Diagnóstico da área de disposição final de resíduos sólidos de Paiçandu (PR) e proposição de melhorias
}

Kevin Felipe Batista ${ }^{1}$, Ricardo Massulo Albertin ${ }^{1}$ and Frederico Fonseca da Silva ${ }^{2}$

\begin{abstract}
Resumo
Contexto: O aumento da geração de Resíduos Sólidos Urbanos (RSU) e sua disposição inadequada é um grande problema a ser enfrentado pela administração pública, no entanto, o aterro sanitário é uma das soluções para tal situação, com o intuito de evitar a má disposição desses resíduos e diminuir os impactos ambientais causados por eles. O presente estudo buscou diagnosticar o sistema de disposição final de RSU do município de Paiçandu (PR) e propor melhorias na infraestrutura existente. Método: Foi realizada visitas no local para identificar as possíveis irregularidades do sistema, tanto na infraestrutura quanto na operação. Desse modo, uma importante ferramenta para auxiliar o diagnóstico e a avaliação foi o Índice de Qualidade de Aterro de Resíduos (IQR), onde, com o acompanhamento do técnico responsável pelo local, foi preenchido todo o questionário. Após identificada as condições do local, iniciou-se, com o respaldo de normas técnicas, o desenvolvimento das regularizações necessárias para o sistema, juntamente com algumas propostas de melhorias. Resultados: De acordo com o levantamento executado, a nota obtida no IQR foi 5,4, o que caracteriza o sistema em condições inadequadas. A área não possui drenagem pluvial e a drenagem de chorume e gás estão comprometidas, além da vala existente estar ultrapassando seu limite, ou seja, está saturada. A operação do sistema deixa a desejar, uma vez que terceiriza os maquinários e não possui funcionários suficientes. O perímetro do terreno não possui cercamento e isolamento visual adequado, o que acaba gerando transtornos para os lotes e moradores vizinhos. Portanto, de acordo com o IQR, o local de disposição final de resíduos não pode ser considerado como um aterro sanitário.
\end{abstract}

\section{Palavras-chave}

Aterro sanitário, Lixão, IQR, Área degradada

\section{INTRODUÇÃO}

Atualmente, uma das problemáticas do meio urbano está relacionada aos resíduos gerados pela população. A geração de resíduos é uma situação que precisa ser evitada, porém, até que esse objetivo seja atingido, deve-se tratar e destinar os resíduos gerados da forma correta, com o propósito de causar o menor dano possível ao meio ambiente e à sociedade. É necessário que a visão de um futuro melhor seja de todos. Assim, em 2010, com o intuito de alterar o cenário do País nesse quesito, foi criada a Política Nacional de Resíduos Sólido (PNRS), constituída pela Lei Federal nº 12.305 (ABNT 2010). A partir daí, ficou proibida a disposição

\footnotetext{
${ }^{1}$ Faculdade de Engenharias e Inovação Tecnológica, Curitiba, Paraná, Brasil

2 Instituto Federal do Paraná, Curitiba, Paraná, Brasil

Emails: kevin_pdu@hotmail.com (Kevin Felipe Batista), ricardomalbertin@gmail.com (Ricardo Massulo Albertin)

Corresponding author:

Frederico Fonseca da Silva, Instituto Federal do Paraná, Curitiba, Paraná, Brasil

Email: prof.frederico.silva@gmail.com
} 
final desses resíduos em aterros controlados e lixões, desse modo, ficaram obrigados os municípios a implantar medidas técnicas adequadas para solucionar o problema de tratamento e disposição final.

Dessa forma, dentre as soluções mais viáveis, com o intuito de minimizar os impactos ambientais e reduzir danos à saúde e segurança pública, propõe-se o descarte desses materiais em áreas adequadas de disposição final ambiental, ou seja, em aterros sanitários, de acordo com NBR 8.419 (ABNT 1992). Ainda de acordo com a referida norma, diferente de lixões e aterros controlados, tal sistema de descarte de resíduos sólidos domésticos, comerciais e também do lodo proveniente do sistema de tratamento de esgoto, baseia-se em princípios de engenharia e é fiscalizado por órgãos ambientais.

Essa pesquisa é de grande importância para esclarecer às pessoas sobre os pontos positivos, diminuir o preconceito para com esse sistema e conscientizar a sociedade quanto ao consumo de produtos recicláveis e que possuem um menor dano ao meio ambiente. Apesar desse tipo de atividade desvalorizar as regiões mais próximas do local, é algo que pode facilitar a organização e higienização do lixo da cidade.

Define-se como aterro sanitário um local cujo objetivo é destinar os RSU de forma apropriada e no menor volume possível, evitando prejudicar a população e o meio ambiente. Método este que tem como respaldo estudos de engenharia e normas técnicas (ABNT 2010).

Existem diferentes formas de se construir a estrutura de um aterro, porém a presente pesquisa teve como base o método da trincheira, onde são escavadas valas com células sobrepostas que foram dimensionadas tecnicamente. A NBR 13.896 (ABNT 1997) descreve as condições mínimas para projeto, implantação e operação de aterros sanitários.

Conforme o que a NBR 15.849/2010 descreve, a impermeabilização da base e lateral pertencente à trincheira é de extrema importância para não infiltrar chorume no solo e a mesma, na região da base, deve ser coberta por $60 \mathrm{~cm}$ de argila a fim de evitar danos oriundos de veículos pesados e resíduos pontiagudos. Além disso, a Norma ressalva que o líquido produzido pelos resíduos é canalizado para os drenos de chorume, esses possuem geralmente inclinação mínima de $2 \%$, que fazem o transporte do mesmo até a estação de tratamento. Refere-se ainda que o gás produzido é expelido pelos drenos que auxiliam na diminuição de pressão. Vale ressaltar que esses gases são altamente poluentes, e para a situação entre o local e as demais áreas externas ao entorno, com o intuito de diminuir os impactos, recomenda que o perímetro do terreno seja protegido por uma cerca e por uma vegetação que ajuda na canalização da ventilação para evitar mau cheiro.

O método de recirculação do lixiviado, sistema existente no local, consiste em enviar de voltar à célula o líquido que escorreu dos resíduos, porém, ainda se faz necessário um sistema de tratamento que possibilite o lançamento desse líquido a um curso d'água (Reichert and Projeto 2007). Quanto à drenagem de águas pluviais, uma das recomendações é abrir uma canaleta em volta de todo $\mathrm{o}$ aterro, de forma a dar caimento necessário à cobertura diária do aterro e eludir escoamentos (CREA, 2009).

No Brasil, o cenário referente à destinação de RSU não se encontra numa boa situação quando comparado à disponibilidadede recursos e ferramentas disponíveis para tratar tal situação. Segundo o Panorama (ABRELP, 2019), em 2018, dos 72,7 mi. de ton. de RSU coletadas, cerca de 59,5\% foram destinados em aterros sanitários. Assim, do restante, 23\% para aterros controlados e $17,5 \%$ para lixões, ou seja, 40,5\% foi despejado em locais inadequados perante a lei. Ainda de acordo com o Panorama, conclui-se então, que houve uma expansão de 2,4\% na disposição final correta em relação ao ano de 2017.

O Paraná tem se destacado nas pesquisas referentes à destinação de RSU. Segundo o Relatório da situação da disposição final de RSU no estado do Paraná, apenas 46,4\% das cidades destinavam corretamente os resíduos, porém nesse mesmo relatório, em 2017 , esta porcentagem subiu para $75,4 \%$, sendo que, do restante, $18,5 \%$ destinam para aterros controlados, sobrando apenas $6 \%$ que descartam ainda em lixões (SZIGETHY e ANTENOR, 2020).

Portanto, o presente estudo teve por objetivo diagnosticar o sistema de disposição final de RSU do município de Paiçandu (PR) e propor melhorias na infraestrutura existente. E, para viabilizar esse objetivo, como suporte, utilizou-se desses objetivos específicos: Identificar as características, situações e operações irregulares do sistema; avaliar a área e todo o sistema atual de disposição final de RSU; e, projetar a readequação juntamente com propostas de melhorias.

\section{FUNDAMENTAÇÃO TEÓRICA}

A diversidade de RSU de um município é enorme. As características relativas à quantidade e qualidade variam de acordo com as características do local, dentre elas estão: aspectos climáticos, demográficos, econômicos e turísticos. Além disso, há chances de mudar conforme alterações na população que gera o resíduo, devido aos hábitos e padrões de vivência. Pode variar até mesmo com uma modificação na economia do país, no grau de renda da população, e assim por diante (Reichert and Projeto 2007).

A busca pela sustentabilidade tem se tornado cada vez mais importante em meio aos planos estratégicos do Ministério do Meio Ambiente (MMA). Após vinte anos de tramitação no Congresso Nacional, a Lei ${ }^{\circ} 12.305$ (ABNT 2010) que aprova a PNRS, eveio com algumas prioridades, tais como acabar com lixões até 2014, implantar coleta seletiva, compostagem de resíduos úmidos e logística reversa. Tais objetivos são um tanto quanto desafiadores para o poder público, de maneira mais específica, principalmente para os municípios, que são responsáveis pela limpeza pública. Após o ano de 2012, a lei disponibilizou convênio e prioridade para 
o repasse de recursos federais, relacionados a esse propósito, para as cidades e estados em que se encontram com o Plano de gestão de RSU firmados.

Em termos de definição, a NBR 10.004 (ABNT, 2004) conceitua resíduos sólidos ou semissólidos, todo material proveniente de ação industrial, hospitalar, comercial, doméstica, agrícola, de varrição e serviços, bem como lodos oriundos de sistema de tratamento de água, gerados em aparelhos e instalações de manejo de poluição e líquidos que, devido a sua composição, sejam impossibilitados de lançar na rede pública de esgoto ou em corpos hídricos, ou necessitem ainda, de prática econômica e tecnicamente inexecutável.

Porém, a temática é mais abrangente do que a Norma expõe. Seu foco principal é a classificação dos resíduos, levando em consideração classe I (perigosos) e classe II (não perigosos). Um resíduo pode ser perigoso quando apresentar características físicas, químicas ou infectocontagiosas, por possuir potencial de prejudicar a saúde pública, ocorrendo mortalidade e/ou aumento de doenças e riscos ao meio ambiente, em situações que o resíduo for gerido de maneira incorreta (ABNT, 2004).

No Brasil, a disposição final dos RSU é feita basicamente de três formas. Em lixões, é o local onde os resíduos são depositados sobre o solo de forma direta, sem controle ou qualquer tipo de cuidado ambiental, prejudicando o solo, o ar e as águas subterrâneas e superficiais da região ao entorno, causando vários impactos ambientais negativos, e, portanto, um método irregular perante a lei; Em aterro controlado, cujo local da disposição é formado basicamente pelo mesmo sistema de um aterro sanitário, a diferença é que não possui coleta e tratamento de chorume e nem drenagem e queima do biogás gerado pela decomposição da matéria orgânica ali disposta (Monteiro et al. 2001). E por fim, em aterro sanitário.

A NBR 15.849 (ABNT 2010), define aterro sanitário como um método de disposição dos RSU na camada superficial dacrosta terrestre, sem ocasionar danos à segurança e saúde pública e minimizando os impactos ambientais, técnica esta que se baseia em estudos de engenharia para destinar esses resíduos à menor área permissível e sintetizá-los ao menor volume possível. O método da trincheira consiste numa disposição realizada em local escavado e enclausurado por três lados, oportunizando assim uma operação mecanizada (Figura 3).

De acordo com o Panorama (ABRELPE, 2019), o Brasil teve uma geração de RSU de 79 milhões de toneladas. Dessa quantia, $92 \%$ foram coletados, ou seja, cerca de $6,3 \mathrm{mi}$. de ton. de resíduos foram destinados para locais inadequados. Traz ainda que apenas aproximadamente $59,5 \%$ desses resíduos foram destinados para aterros sanitários. Assim, estima-se que 29,5 milhões de toneladas de RSU terminaram em lixões, aterros controlados, enfim, para sistemas que não possuem estrutura correta e necessária para a disposição dos resíduos. Entretanto, a região Sul possui uma realidade um pouco diferente, ainda diante dos dados da Abrelpe (2019), aproximadamente $87 \%$ dos municípios destinam seus resíduos para aterros sanitários.

Para o êxito do projeto, instalação e operação desse sistema, são exigidas certas condições relativas à localização, segregação e análise de resíduos, monitoramento, inspeção, treinamento de pessoal e fechamento da instalação (ABNT 1997). Como resultado desse processo, garante-se a proibição da presença de catadores, diminui a presença de vetores e aumenta o controle da poluição gerada.

O método abordado parte do princípio da localização, como existência de solo com característica pouco permeável, proximidade do lençol freático em relação à base do aterro, ocorrência de inundações na área, declividade do terreno entre 1 e $30 \%$, ter no mínimo $500 \mathrm{~m}$. de distância do limite da área útil até núcleos populacionais, distância mínima de 200 m., no caso de existência próxima, de corpos d'água. Entretanto, tais requisitos podem ser alterados se apresentado justificativa técnica plausível pelo projetista (ABNT 2010).

Como denota a NBR 15.849 (ABNT 2010), a impermeabilização é um elemento que protege o meio ambiente, destinado a confinar os resíduos de solo natural de modo a minimizar a infiltração de lixiviados e de biogás. Elemento este denominado como manta geossintética, de liga plástica, elástica e flexível. Além disso, toda área da manta deve ser coberta com uma camada de argila de, aproximadamente, $60 \mathrm{~cm}$ de modo a evitar que os resíduos e veículos de operação danifiquem a manta e permita acesso para o solo inferior.

O sistema de drenagem, além de fundamental para uma operação estável do sistema e obrigatório, se subdivide em três tipos: de águas pluviais que consiste num conjunto de estruturas que tem como objetivo captar e dispor de forma adequada as águas da chuva incidentes sobre as áreas aterradas e seu entorno (ABNT 1997). Tal sistema deve ser condicionado com as precipitações do local de modo a não permitir a entrada dessa água escoada ao maciço do aterro e nem desvio de material sólido e líquidos percolados para fora do perímetro do aterro (ABNT 2010). Os drenos de água pluvial devem ser inspecionados depois de tempestades, para garantir a operação (ABNT 1997).

A drenagem de lixiviados tem por objetivo possibilitar a remoção e destinação adequada do lixiviado gerado no interior dos aterros. Dessa forma, os drenos de chorume devem ser instalados sobre a impermeabilização, precisam ser dimensionados de maneira a evitar uma altura de lâmina acima de $30 \mathrm{~cm}$ de líquido, o material utilizado necessita ser resistente aos resíduos e à pressão aplicada sobre durante a vida útil do aterro, além disso, não pode ocorrer obstrução desses canais (ABNT 1997).

As declividades do sistema de drenagem de lixiviado do aterro precisam atingir, aproximadamente, 2\% (ABNT 2010). Além disso, a drenagem do fundo deve ser feita com material que permita espaços livres sem aterrar, por exemplo, materiais 
rochosos (Reichert and Projeto 2007). Para Christensen et al. (2001), o lixiviado é um fluído escuro e com mau cheiro, gerado a partir da decomposição físico-química e biológica dos resíduos orgânicos.

A drenagem de gases busca possibilitar a remoção adequada dos gases gerados em meio ao aterro é composta por uma manilha de concreto com diâmetro de $50 \mathrm{~cm}$ e perfurada, envolto com uma camada de pedra rachão e uma tela de aço. Devem ser instaladas a $30 \mathrm{~m}$ de distância uma das outras e na junção das tubulações de percolado. Geralmente usa-se um dispositivo de queima na ponta do dreno para diminuir o impacto desses gases ao meio ambiente. Os drenos são instalados por etapas, a modo de que deve estar $1,0 \mathrm{~m}$. acima da altura final de cada vala (ABNT 2010). Seguindo os pressupostos de Castilhos Junior et al (2003), a origem do gás em aterro sanitário é afetada por algumas variáveis, como a umidade, estado físico, $\mathrm{pH}$, temperatura, taxa de oxigenação e sua natureza.

A disposição dos rejeitos no solo não deve interferir na qualidade das águas subterrâneas, inserindo características indesejadas e que fogem de sua classificação. Desse modo, é indispensável que exista o monitoramento das mesmas através de poços de monitoramento, sendo exigido ao menos quatro: um a montante e três a jusante da área do aterro sanitário (ABNT 2010).

$\mathrm{O}$ poço à montante deve avaliar a qualidade original da água subterrânea, enquanto os poços à jusante, apesar de ter o mesmo objetivo, são recomendados sua instalação em não alinhamento e de forma transversal ao fluxo subterrâneo, além de precisarem estar localizados perto da área de disposição, com o intuito de perceber algo em desacordo o mais rápido possível (ABNT 1997).

Seguindo a NBR 13.896 (ABNT 1997), um aterro deve possuir cerca que circunde completamente a área em operação, construída de forma a impedir o acesso de pessoas estranhas e animais, cerca viva ao entorno da instalação, quando quesitos relativos à vizinhança, ventos dominantes, com o propósito de reter poeiras resultante da operação do aterro, bem como diminuir o impacto visual e a proliferação de odores nas áreas vizinhas, portão de acesso para o controle de entrada e saída ao local, sinalização nas entradas e cercas com a frase "PERIGO - NÃO ENTRE" e uma faixa non-aedificant com no mínimo $10 \mathrm{~m}$. de largura.

Conforme Reichert and Projeto (2007), a operação do aterro é uma fase muito importante para o sucesso do sistema, ou seja, para que a disposição dos resíduos seja executada de forma a minimizar os impactos ambientais. A disposição correta e bem organizada difere um aterro sanitário de um aterro controlado e/ou lixões. Mesmo que seja uma obra bem projetada e implantada, corre o risco de ter sérios problemas ambientais se tiver uma má operação. É imprescindível que seja adotada boas técnicas de operação para maximizar as habilidades gerenciais e de engenharia do pessoal que atua no local. Por exemplo, o gerente de aterro precisa supervisionar diariamente as atividades, sendo necessários suporte e visitas regulares do engenheiro responsável, a fim de garantir que o projeto e o plano de disposição estão sendo seguidos. Também precisa ter o poder de tomar decisões sobre situações no dia-a-dia e deve ter acesso a suficientes recursos físicos e financeiros.

Para garantir um melhor funcionamento do aterro, são necessárias algumas estruturas auxiliares, como balança, para medir e avaliar a quantidade de resíduos que entram no aterro, tal ato é importante para diagnosticar dados estatísticos que podem ajudar na elaboração de futuros planos de manejo. Os escritórios auxiliam na contabilidade virtual das quantidades pesadas que chegam, do material utilizado, controle de pessoal, entre outros serviços administrativos (Reichert and Projeto 2007).

\section{MATERIAIS E MÉTODOS}

O presente item teve como objetivo apresentar os materiais e métodos, levando em consideração as seguintes abordagens: tipos de pesquisa, caracterização da área de estudo e procedimentos metodológicos.

\section{DEFINIÇÃO DE TIPO DE PESQUISA}

De acordo com Gil and Como (2012), a pesquisa bibliográfica tem como base material já existente. A vantagem desse tipo de pesquisa é permitir ao indivíduo uma ampla e maior cobertura relativa ao fenômeno pesquisado quando comparado com pesquisas de forma direta, tornando-a muito importante em situações que o problema exige dados muito dispersos. Porém, algumas fontes fornecem informações equivocadas e um trabalho precisa assegurar as condições de seu conteúdo. A maneira para evitar falsos ou incompletos dados, é diagnosticar em profundidade cada informação e utilizar várias fontes. Dessa forma, o tema abordado nesse trabalho se enquadra nesse tipo de pesquisa pois requer uma enorme gama de conteúdo advindo de livros, artigos científicos entre outros do gênero.

Segundo Bogdan (2003), a pesquisa qualitativa envolve a obtenção de informações, coletadas no contato direto do pesquisador com a situação estudada, primazia mais o processo do que o produto. Para Silva (2014), numa pesquisa qualitativa, estão envolvidas características como qualificação dos dados, avaliação da qualidade das informações e percepção dos atores sociais, concluindo que esse método não se preocupa com medidas. Pois há uma preocupação priorizada com o processo em geral deste sistema, tanto construtivo quanto operacional.

Ao que diz respeito à pesquisa do tipo levantamento, tal método acontece, basicamente, mediante a questionamentos a um grupo significativo de indivíduos em relação à situação estudada, assim, após análises quantitativas, obtém-se resultados correspondentes 
as informações coletadas. Em geral, não são questionadas todas as pessoas, pois quando isso ocorre, é denominado como censo, e este é um procedimento um tanto quanto mais complexo e executado apenas pelo governo ou por instituições com grandes recursos (Gil and Como 2012).

Dentre as principais vantagens desse método (Gil and Como 2012), pode-se citar o conhecimento direto da realidade; economia e rapidez, uma vez que os dados são coletas por meio de questionários, tornando os custos relativamente baixos; quantificação, as informações podem ser passadas para tabelas, tornando a análise mais fácil. Porém existem algumas limitações, como recolher dados de pensamento e/ou percepção própria do indivíduo, correndo o risco de resultar em informações distorcidas; oferece uma situação petrificada do problema, não indicando possíveis alterações estruturais.

De acordo com Mattar (2001), a pesquisa quantitativa busca a validação das hipóteses por meio da utilização de informações estruturadas, estatísticas, com análise de um elevado número de casos representativos, recomendando um caminho final da ação. Silva (2014), descreve esse tipo de pesquisa como algo que necessita de utilização de medidas e procura soluções quantificáveis, além de aplicar o uso de estatística básica e/ou avançada.Assim, a atual pesquisa também se torna quantitativa, pois necessita de dados estatísticos e informações numéricas e estruturadas para o planejamento das adequações e melhorias e embasamento para comprovar a garantia dos resultados.

Seguindo Gil and Como (2012), estudo de caso é uma vertente dos tipos de pesquisa, que procurar estudar de forma profunda o objeto, de modo a detalhar e ampliar o conhecimento sobre o mesmo. Além disso, os resultados de tal estudo, geralmente, é tratado em forma de hipótese e não de conclusão. Portanto, algumas de suas finalidades são: examinar situações da vida real que seus limites não estejam definidos com clareza; apresentar a circunstância do contexto em que está sendo realizada determinada verificação; e, formular hipóteses.

O tema abordado pode ser considerado como um estudo de caso, pois foi necessário coletar e analisar dados do local e/ou situação do sistema de disposição final de resíduos para concluir hipóteses em relação ao local, além de necessitar de um estudo profundo, devido às complexidades envolvidas e relacionadas com o meio ambiente, social e econômico. Na Figura 1 é apresentado um fluxograma onde expõe as etapas envolvidas na realização da pesquisa.

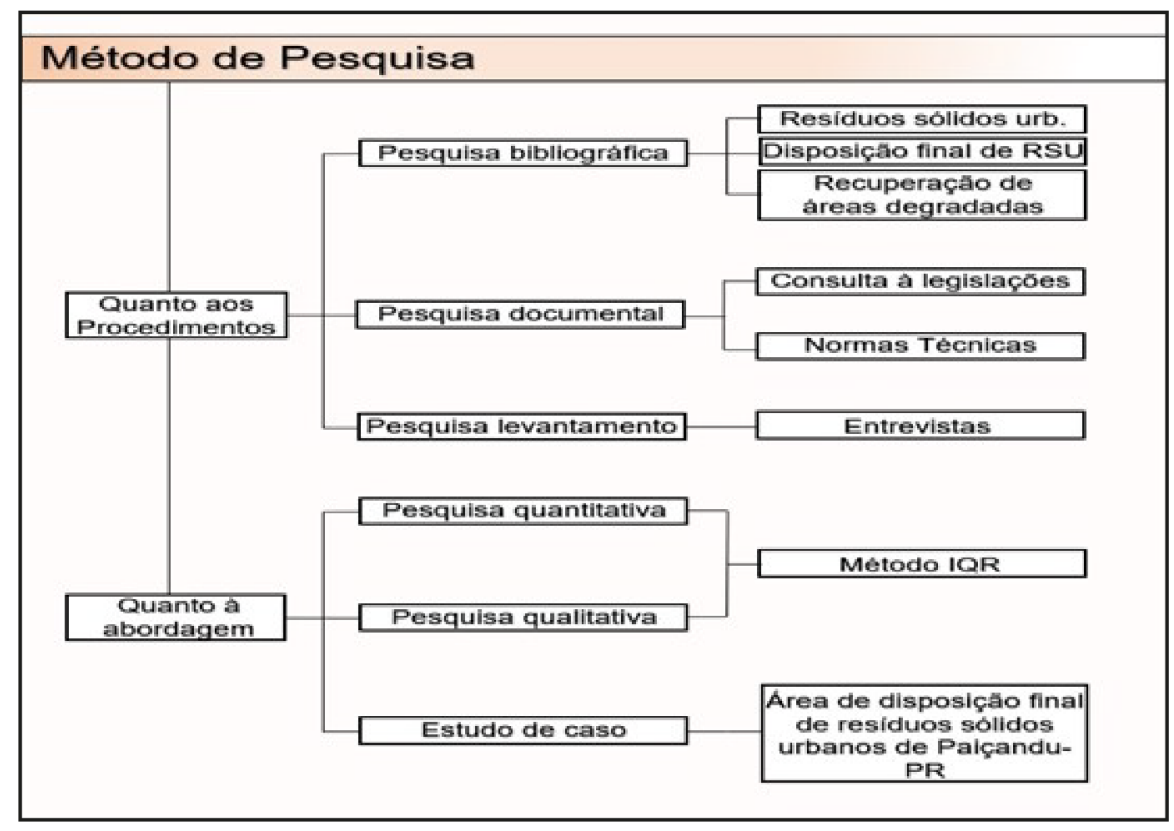

Figure 1. Fluxograma da Pesquisa 


\section{CARACTERIZAÇÃO DA ÁREA DE ESTUDO}

A área de estudo abrangerá a cidade de Paiçandu (PR), na rodovia PR 323 no eixo Maringá - Cianorte. Possui uma população estimada (IBGE, 2019) de 41.281 habitantes, uma área territorial de 171,38 km² (IBGE, 2019), incluindo o distrito de Água Boa e uma densidade demográfica de 209,69 hab./ $\mathrm{km}^{2}$ (ABNT 2010).

O município tem como principal atividade econômica a indústria e agropecuária. $\mathrm{O}$ abastecimento de água ocorre por meio dos serviços da SANEPAR, que retira a água de poços artesianos. O relevo pode-se considerar relativamente plano, com altitude média de $438 \mathrm{~m}$ acima do nível do mar (TOPOGRAPHIC-MAP, 2020). A Figura 2 demonstra a localização do local de disposição final de resíduos sólidos em relação ao centro urbano da cidade.

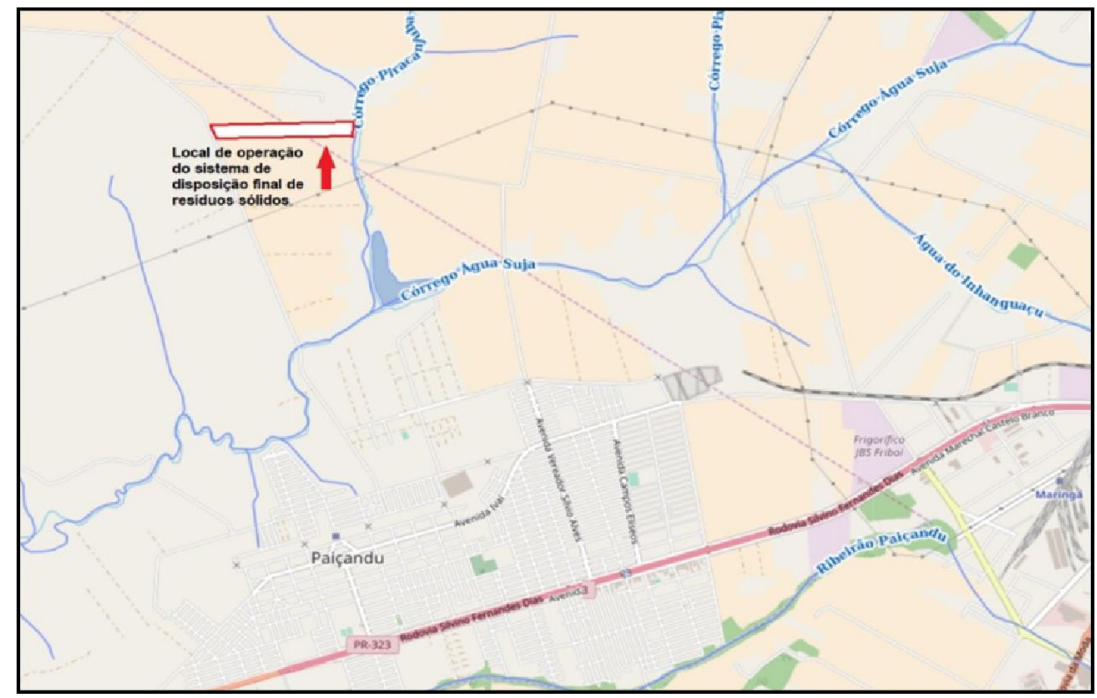

Figure 2. Localização da área de disposição final de resíduos sólidos do município de Paiçandu (PR) - Fonte: Google Maps (2020)

Segundo Rosado (2018), 40.156 habitantes são contemplados com a coleta de lixo, que é de responsabilidade de uma empresa contratada, com uma média de $21.730 \mathrm{~kg}$ /dia. Há também um sistema de coleta seletiva terceirizado no município. É importante salientar que a coleta seletiva tem uma grande importância para um sistema de disposição final de resíduos sólidos, pois reduzindo os resíduos destinados para o mesmo a vida útil do aterro sanitário aumenta (Figura 3).

O local onde opera o sistema de disposição final de resíduos sólidos conta com uma área de, aproximadamente, 10 hectares (Figura 4) e, de acordo com Rosado (2018) Rosado (2018), recebe cerca de 652 ton./mês. Segundo a Portaria nº 259 (PARANÁ, 2014), o mesmo é classificado como categoria "A" (capacidade de recebimento de resíduos $<200$ ton./dia).

De acordo com Embrapa (2007), o solo predominante do local é o latossolo vermelho distroférrico. Esse tipo de solo apresenta cores vermelhas acentuadas, ocasionadas pelos teores mais altos e à natureza dos óxidos de ferro pertencentes do material de origem em locais bem drenados e atributos de textura, cor e estrutura homogêneos em profundidade. Além disso, é um solo predominante de locais com relevo plano e suave ondulado, contribuindo com a mecanização agrícola. Pelo fato de ser profundo e poroso, demonstra boas condições para o desenvolvimento radicular em profundidade. Pelo fato de ser distroférrico, é um solo de baixa fertilidade e altos teores de ferro. São solos profundos, velhos e evoluídos.

\section{PROCEDIMENTOS METODOLÓGICOS}

O estudo foi desenvolvido em duas etapas, sendo: Diagnóstico, com o intuito de entender a dinâmica do meio físico do local e avaliar a área de disposição final de resíduos sólidos; e,planejamento, desenvolvimento e organização das propostas de regularização e melhorias para o sistema existente.

De uma forma mais específica, no meio físico, foi diagnosticado o tipo de solo, geologia, relevo (declividade), cursos hídricos (superficial e subterrâneo), dados estes obtidos por fontes secundárias como o Instituto de Terras, Cartografia e Geologia do Paraná 


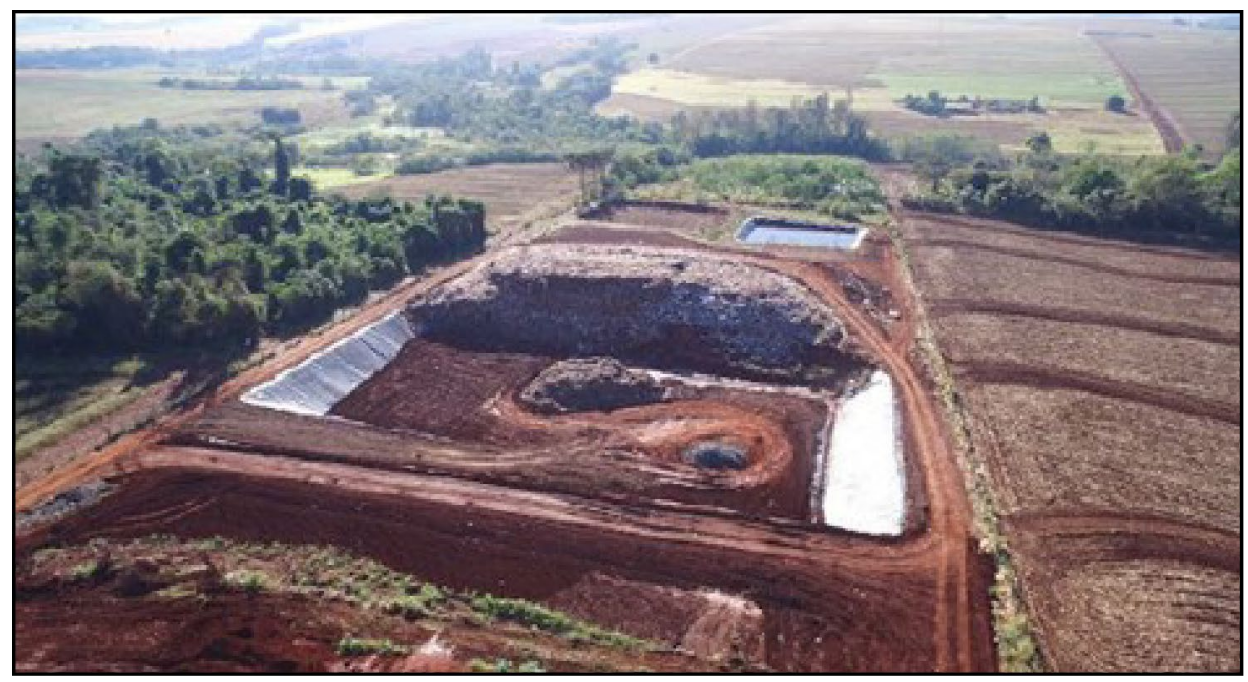

Figure 3. Vala existente no sistema de disposição final de resíduos sólidos - Fonte: Secretaria Municipal de Meio Ambiente Paiçandu (PR)

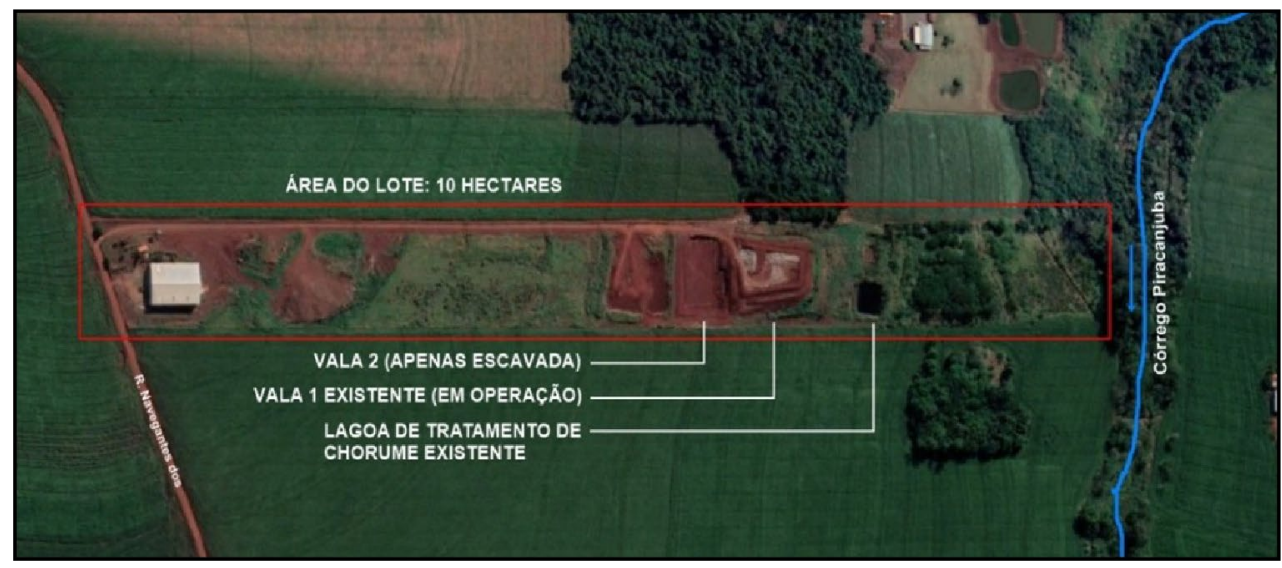

Figure 4. Imagem aérea da disposição final de resíduos de Paiçandu (PR) - Fonte: Google Maps (2020)

e o Sistema de Informações de Águas Subterrâneas. No meio biológico, foi verificado junto com técnico responsável a existência de Área de Preservação Permanente e Reserva Legal. E por fim, quanto à estrutura e operação da área de disposição final foi avaliada por meio do Índice de Qualidade de Aterro de Resíduos (IQR).

Ao que diz respeito à primeira etapa, antes de iniciar o trabalho, realizou-se uma pesquisa técnica para verificar a situação atual da área de disposição final de resíduos sólidos do município.

Dessa forma, em busca de sanar as dúvidas em relação ao funcionamento e operação do sistema de descarte de resíduos sólidos, realizou-se uma visita técnica in loco, acompanhada pelo técnico responsável, na data de setembro de 2020, onde foi aplicado o IQR que, de acordo com a CETESB (2019), refere-se a um questionário cujas características locacionais, estruturais e operacionais das instalações de compostagem e de disposição final de resíduos são avaliadas, e, a partir dessas informações, é possível indicar as condições ambientais do local. 
Já em relação à segunda etapa, a ideia foi utilizar o método IQR para identificar e verificar os possíveis erros de infraestrutura e operacional e, com base nisso foi possível propor algumas regularizações e melhorias.

\section{RESULTADOS E DISCUSSÕES}

A área de disposição final, objeto deste estudo, sofre constantemente de reclamações dos habitantes, principalmente dos moradores próximos do local. De acordo com as contestações da população, o sistema apresentava irregularidades, tanto em equipamentos quanto na operação e estrutura, ocasionando danos ao meio ambiente e à sociedade.

Mas que, em relação à localidade (ABNT 1997), descreve que também deve estar de acordo com o permitido no zoneamento da região, a aceitação da população seja majoritária, precisa ser um local que o impacto ambiental seja amenizado, possua espaço para ser utilizado por um longo tempo e os acessos internos e externos ao local precisam estar em condições acessíveis sob quaisquer condições climáticas. Portanto, como o sistema é existente, entende-se que na época em que foi implantado, como aterro sanitário, o local atendia todas as especificações, considerando que foi preciso aprovação de órgãos do governo para execução.

O terreno, atualmente, possui uma vala existente onde a mesma já passou pela implantação de todo o sistema de impermeabilização, drenagens entre outros procedimentos necessários para a disposição de resíduos, e encontra-se em uso. Além disso, existe também uma vala que até o presente momento está apenas escavada, esperando pela implantação do sistema e assim iniciar seu uso para disposição de resíduos.

Portanto, para melhor entendimento, as valas serão denominadas de vala 1 identificada como a que, atualmente, recebe resíduos, está em operação (possui sistema necessário para disposição de resíduos); e, vala 2, como a que está apenas escavada, esperando pela implantação do sistema necessário para iniciar seu uso para disposição de resíduos sólidos.

\section{DIAGNÓSTICO E AVALIAÇÃO DA ÁREA DE DISPOSIÇÃO FINAL}

O IQR aplicado resultou numa nota de 5,4, ou seja, o sistema de disposição final de resíduos sólidos de Paiçandu (PR) está em condições inadequadas, sendo necessário, no mínimo, nota7,0 para se enquadrar nas condições adequadas.

$\mathrm{Na}$ entrada de acesso ao local há um pavimento destinado a guarita e outro destinado a vestiário e banheiro (Figura 5). Porém não há funcionários para recepção na guarita. Existe um caseiro para cuidar do local, onde também lá mora.

A balança existente possui um pavimento ao lado para operação do maquinário da mesma (Figura 6), porém não está em funcionamento devido ao furto de peças. O município terceiriza boa parte dos maquinários necessários para operar o local e não existem funcionários suficientes para todas as funções necessárias para uma boa operação. Logo na entrada do lote, há uma caixa d'água e um poço artesiano, este possui outorga de acordo com o técnico responsável.

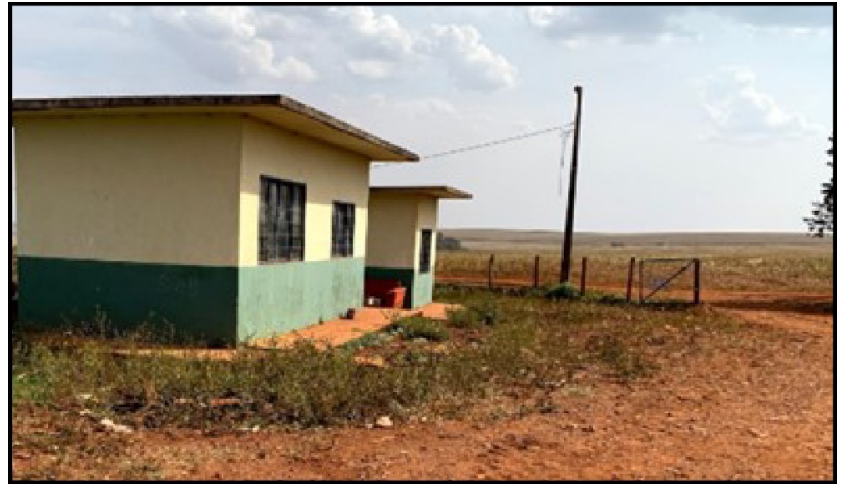

Figure 5. Entrada do lote - Fonte: Autores

Existe um barracão ao lado da entrada de acesso ao local, onde funciona hoje o processo de triagem e separação de reciclável do lixo que chega ao local nos caminhões. Uma empresa que ganhou a licitação administra esse procedimento.

De acordo com a NBR 13.896 (ABNT 1997), o local não possui cercamento adequado para o tipo de trabalho operado. Além disso, não existe cortina verde (Figuras 7 e 8). Outro fator a ser analisado é a maneira que passa a fiação elétrica, bem próxima da 


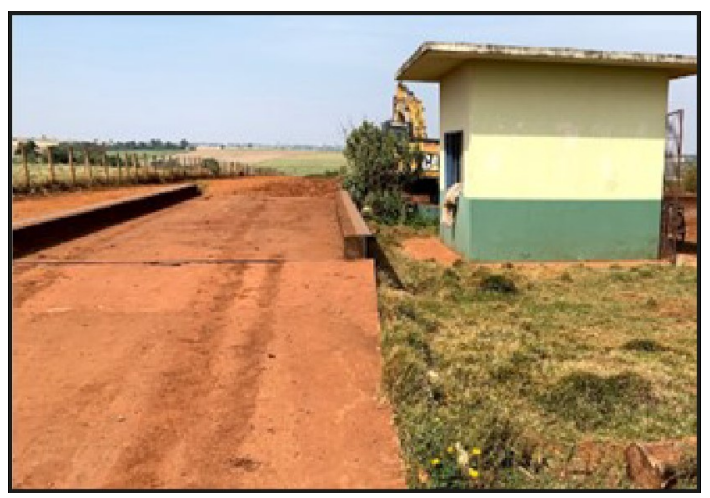

Figure 6. Balança - Fonte: Autores

divisa do lote e, por isso, pode ser um empecilho para a implantação da cortina verde.É grande a quantidade de sacos plástico que dispersam para fora da vala. Com isso, há a preocupação com o lote ao lado que realiza plantações sazonais.

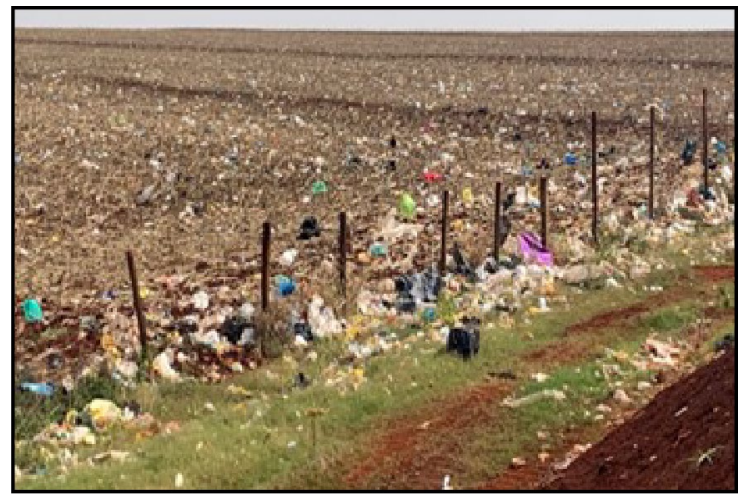

Figure 7. Vista para o lote vizinho - Fonte: Elaborado pelos autores (2021)

Portanto, ao passar do tempo, foi-se necessário executar algumas readequações de urgência e, infelizmente, algumas irregulares, podendo citar como exemplo as células sobrepostas da vala existente mesmo depois de encerrada sua vida útil e a escavação e cobrimento com pedra rachão no ponto de intersecção da drenagem de chorume, escavação essa que ocorreu pois o ponto de intersecção dos drenos de chorume estava comprometido e entupido, então foi executado um procedimento onde foi escavado, reparado o local/tubulação e feita uma camada de pedra rachão, para não entupir totalmente a drenagem de chorume.

A vala 1 não possui drenagem de gás, devido ter sido soterrado no processo de cobrimento com lixo e solo, não se sabe ao certo quando ocorreu tal ato. Em alguns pontos, na beirada da vala, próximo ao término da geomembrana, porém ainda dentro de seu domínio, existe o acúmulo de água da chuva numa valeta escavada num período do final do ano de 2019 onde houve uma enorme precipitação e, para evitar que a água com chorume extravasasse da geomembrana, executou-a para escoar as águas pluviais. Há ainda o afloramento de gases em um dos lados do talude na lateral da vala.

A drenagem de chorume da vala 1 não é totalmente eficaz, em observação ao poço de inspeção de chorume, a vazão que passa e é destinada para a lagoa é pequena comparada com o porte da vala existente, podendo concluir que a tubulação está parcialmente 


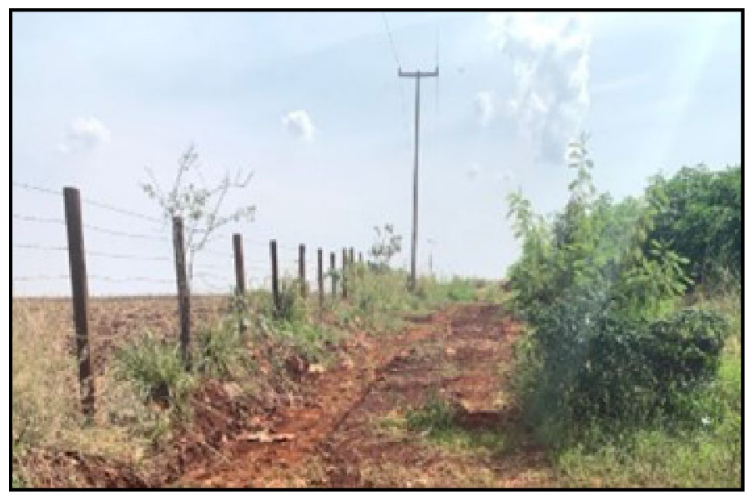

Figure 8. Cercamento existente - Fonte: Elaborado pelos autores (2021)

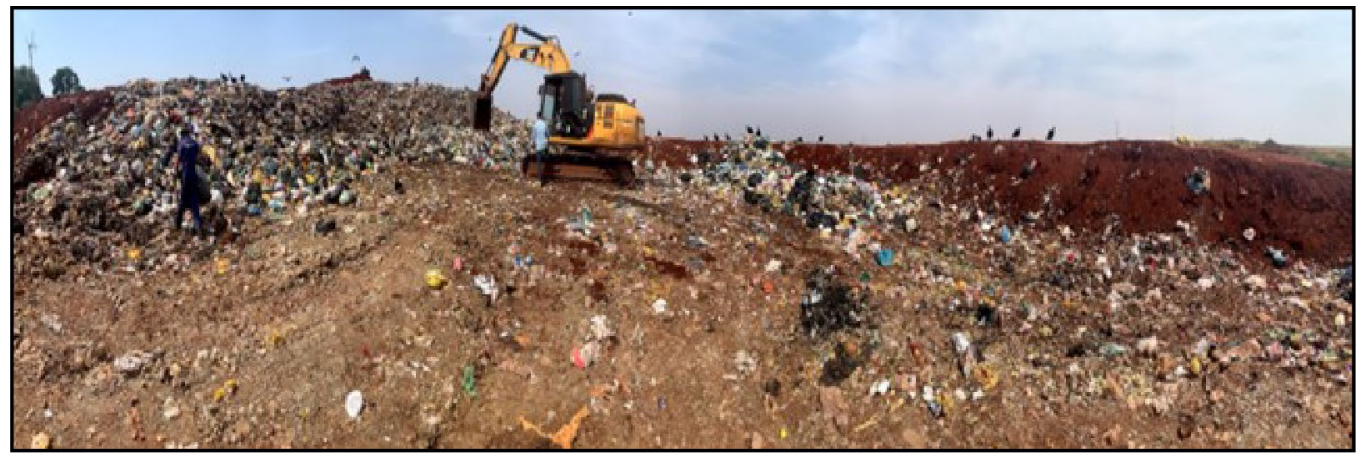

Figure 9. Vala 1 - Fonte: Elaborado pelos autores (2021)

entupida em algum local. A lagoa de tratamento de chorume (Figura 10) está com a geomembrana danificada em alguns pontos (Figuras 11 e 12). Portanto, há o risco de dano ao solo se o nível da mesma se elevar até os locais do dano. A drenagem de águas pluviais é feita por meio de curvas de níveis do terreno. Portanto, não há uma estrutura de canalização das águas pluviais para um recipiente pré-determinado.

Devido o terreno estar situado numa marginal de um curso d'água, deve possuir APP, onde a mesma necessita ter, no mínimo, uma faixa de 30m. de largura contando a partir da borda da cala do leito, de acordo com a Lei 12.651 (BRASIL, 2012). O terreno, por ser um imóvel rural, também deve possuir uma área de Reserva Legal com vegetação nativa. Ambas as áreas estão localizadas no fundo do lote as margens do Rio Piracanjuba. Além disso, a estrada de acesso ao local não possui pavimentação asfáltica, o que dificulta o acesso em dias chuvosos.

\section{MELHORIAS PARA ÁREA DE DISPOSIÇÃO FINAL}

Com base no diagnóstico e avaliação por meio do IQR, elaborou-se propostas de readequações e melhorias para o gerenciamento adequado do local de disposição final de resíduos sólidos (Quadro 1). 
Quadro 1.Melhorias estruturais propostas para a área de disposição final de resíduos sólidos do município de Paiçandu (PR)

Table 1. Melhorias estruturais propostas para a área de disposição final de resíduos sólidos do município de Paiçandu (PR)

\section{ÍTEM}

Balança

Cercamento

Cortina verde

Drenagem de águas pluviais

Acondicionamento de águas pluviais

Geomembrana danificada na lagoa de tratamento de chorume

Tratamento de chorume

Vala existente (Vala 1)

Nova vala (Vala 2)

\section{PROPOSIÇÃO DAS MELHORIAS}

Adquirir peças faltantes para a operação da pesagem do lixo

Implantar cercamento em todo o perímetro do lote

Implantar cerca viva arbustiva ou arbórea no perímetro

Instalação de sistema de drenagem de águas pluviais

Implantar lagoa de acumulação de água pluvial

Executar reparos na geomembrana

Contratar empresa especializada para remover o chorume acumulado na lagoa de tratamento e destine-o corretamente. Devido ao fato de haver apenas a recirculação do líquido

Encerrar urgentemente a vala existente da maneira correta e com devido cuidado

Implantar todo sistema necessário para disposição dos resíduos na vala escavada existente (vala 2), seguindo os critérios de dimensionamento e execução dispostos nas normativas (ABNT NBR 15.849 (2010); 8.419 (1992); 13.896 (1997)

Adaptado de ABNT (ABNT 2010)

O Quadro 2 demonstra as propostas desenvolvidas para melhorar a operação do sistema de disposição final de resíduos sólidos.

Table 2. Melhorias operacionais propostas para a área de disposição final de resíduos sólidos do município de Paiçandu (PR)

ÍTEM PROPOSIÇÃO DAS MELHORIAS

- Portaria - Contratar/direcionar funcionário para a devida função de porteiro

- Vigilância - Contratar/direcionar funcionários para a vigilância e segurança do local

- Balança - Contratar/direcionar funcionário com domínio do equipamento para manuseio e operação

- Maquinários - Adquirir equipamentos próprios com o intuito de minimizar o gasto com equipamentos terceirizados

Fonte: Elaborado pelos autores (2021) 


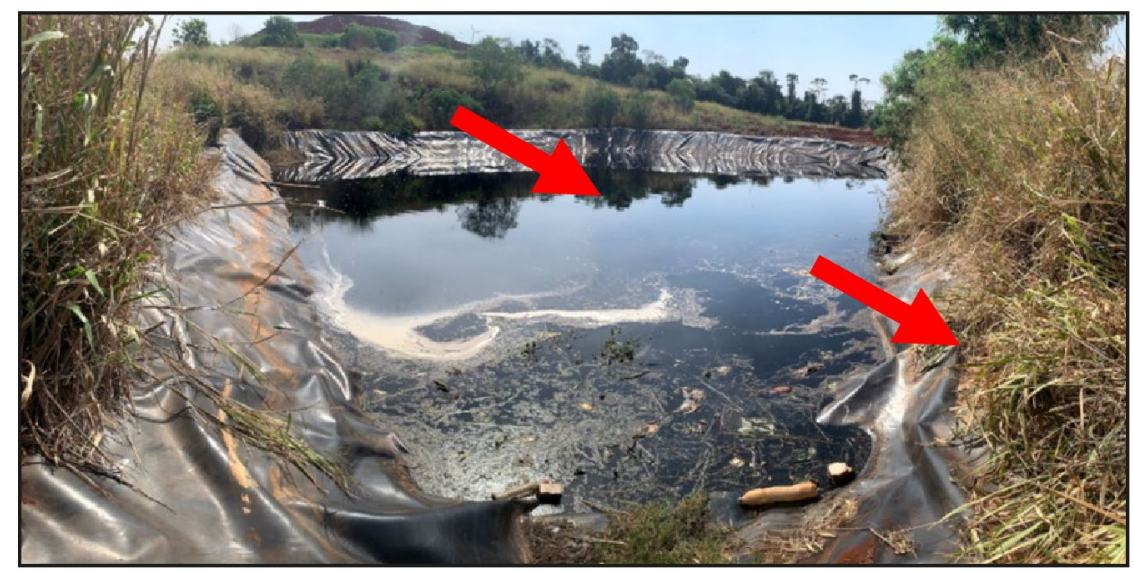

Figure 10. Lagoa de tratamento de chorume - Fonte: Elaborado pelos autores (2021)

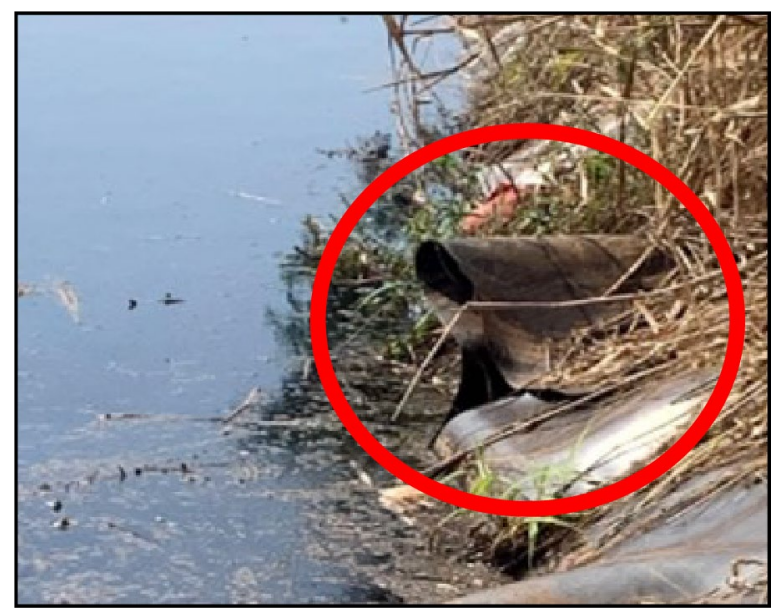

Figure 11. Danos na geomembrana da lagoa de tratamento dechorume

De modo a evitar o ingresso de pessoas não autorizadas na área do aterro, é aconselhado que seja implantado um cercamento em todo o perímetro do lote. Recomenda-se ainda que essa cerca possua, aproximadamente, 2,0 m. de altura, com moirões de concreto, onde passem cinco fios de arame galvanizado ou farpado com espaçamentos homogêneos. Além disso, é necessário também um cinturão verde, que tem como objetivo impedir a vista da área operacional, dispersar o mau cheiro do lixo e impedir que sacos plásticos e outros objetos voem para fora dos limites do local, conforme Monteiro et al. (2001), nas Figuras 13 e 14.

Reichert and Projeto (2007) relata que ocorreu num aterro sanitário de Porto Alegre, que a cerca de arame farpado não foi suficiente para impedir a entrada de catadores e animais, assim, foi necessário escavar um canal com mais de $10 \mathrm{~m}$ de largura ao redor de toda a área. Assim, recomenda-se uma inspeção semanal no sistema de isolamento, com o intuito de reparar possíveis problemas no cercamento, como fios arrebentados, e até mesmo pragas nas mudas da barreira vegetal.

O sistema de drenagem precisa ser capaz de suportar uma drenagem de modo que impeça: o acesso da água ao maciço do aterro, o carreamento de material sólido e líquidos percolados para fora da área pertencente ao aterro (ABNT 2010), com a finalidade de 


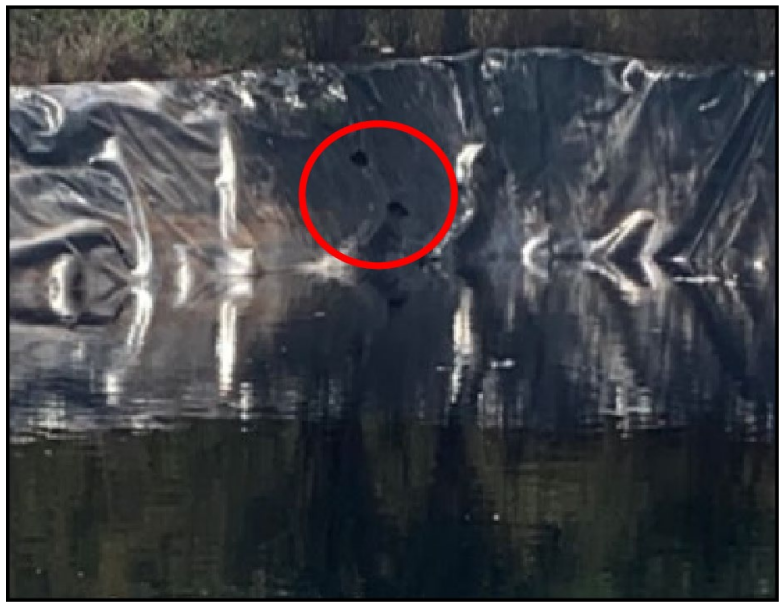

Figure 12. Danos na geomembrana da lagoa de tratamento de chorume - Fonte: Elaborado pelos autores (2021)

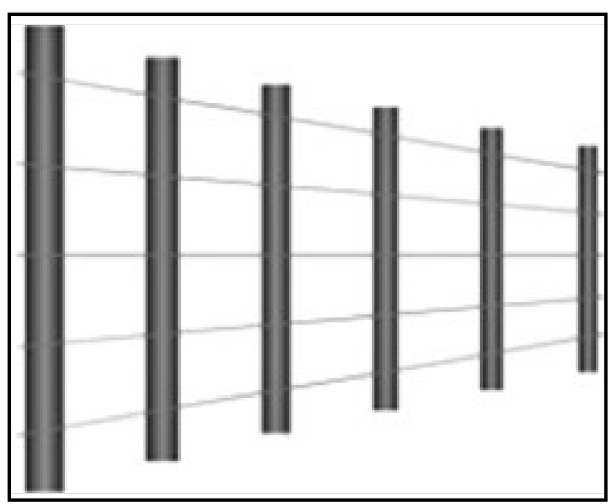

Figure 13. Modelo de cerca

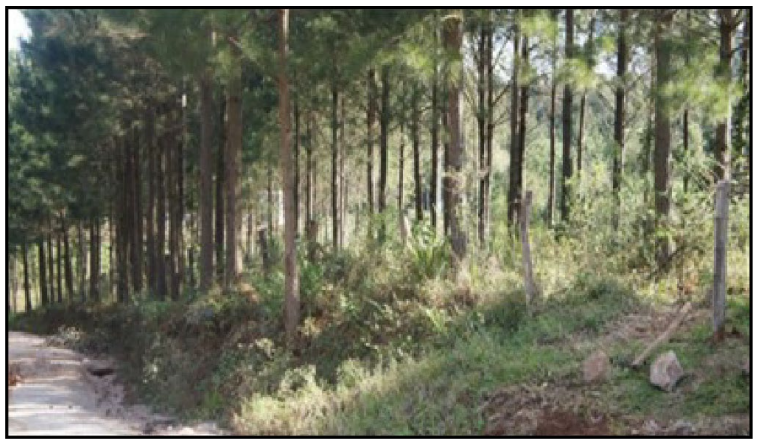

Figure 14. Vegetação no perímetro 
um direcionamento adequado para infiltração no solo.Um dos métodos eficazes para a drenagem de águas pluviais é a instalação de canaletas de concreto (Figuras 15 e 16), mais conhecida como "meia-cana".

A NBR 8.419 (ABNT 1992), orienta sobre a importância da existência de local para descarga da água coletada pelos canais de drenagem superficial, mais conhecido como "lagoa de acumulação de água pluvial", precisa ser dimensionado de acordo com a precipitação da região, área do aterro (célula) e a quantidade de água prevista a ser escoada por meio das canaletas de concreto.

Em relação a danificação da geomembrana, o reparo da mesma geralmente pode ser feito de várias maneiras, a depender do tipo de material. Porém, para geomembrana tipo PEAD, geralmente é utilizado a solda por termo fusão, que consiste no aquecimento das faces a serem emendadas por meio da transferência de calor por cunha metálica ou suflamento de ar e, assim, a soldagem entre as duas faces (COLMANETTI, 2006).

Com base no sistema de tratamento do chorume existente, que ocorre por meio da recirculação do lixiviado, é recomendada a contratação de uma empresa especializada para a remoção do lixiviado da lagoa de tratamento de chorume e, após, executar os reparos na geomembrana.

Levando em consideração a urgência em encerrar a vala 1, é importante ressaltar que o procedimento deve ser executado com cautela, uma vez que a célula está além de seu limite de capacidade de recebimento de resíduos sólidos. Assim, é recomendado uma cobertura final da célula com cerca de $0.60 \mathrm{~m}$. de espessura de solo e, sobre essa camada de argila, o plantio de vegetação gramínea. O objetivo dessa camada de cobertura final é isolar os resíduos do local e diminuir a infiltração de água da chuva para

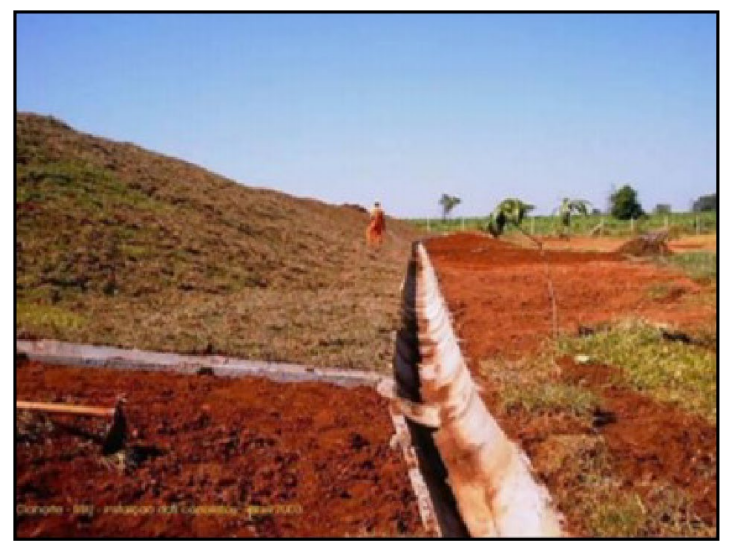

Figure 15. Sistema de drenagem existente no aterro sanitário de Cianorte (PR) - Fonte: Adaptado de Albertin et al. (2011)

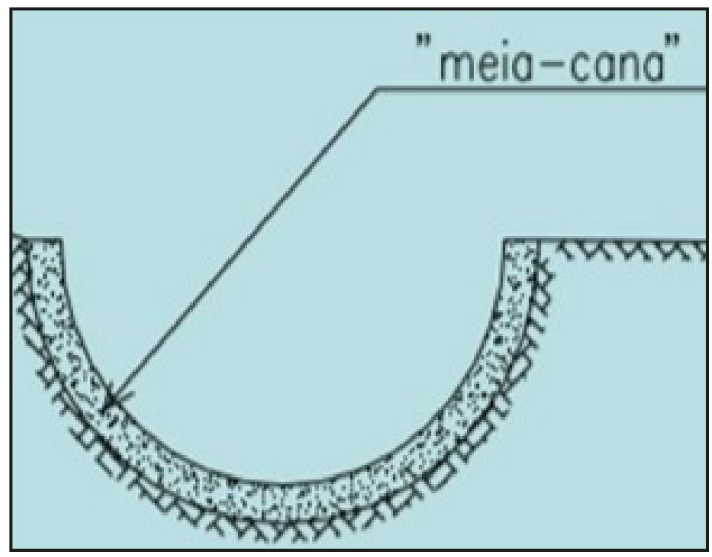

Figure 16. Modelo de canaleta "meia-cana" 
dentro da célula. Essa camada precisa ser flexível de modo a se acomodar aos deslocamentos que ocorrerão futuramente (Reichert and Projeto 2007).

No quesito de implantação de nova vala, considerando a escavação existente (Vala 2), conforme Figura 17, aconselha-se, com urgência, implantar todo o sistema necessário para recebimento de resíduos.

Ao que se refere sobre funcionários capacitados para as funções designadas, é importante que cada funcionário destinado à uma função receba um treinamento/curso para capacitá-lo. De imediato as funções que necessitam de funcionários são: portaria, vigilância/segurança e balança (considerando o funcionamento da balança depois de reparada). Além disso, é necessário que seja concedido aos funcionários todo equipamento necessário para proteção (EPI), de acordo com a NR 6 (ABNT, 2006).

Em relação aos maquinários necessários para operação do sistema, destacam-se alguns de extrema importância, como o trator esteira, usado para espalhar e compactar os resíduos e a cobertura de solo; pá carregadeira, para a operação de carregamento de solo no caminhão basculante e serviços de escavação necessários; e o caminhão basculante para o transporte de solo (ODA, 2009).

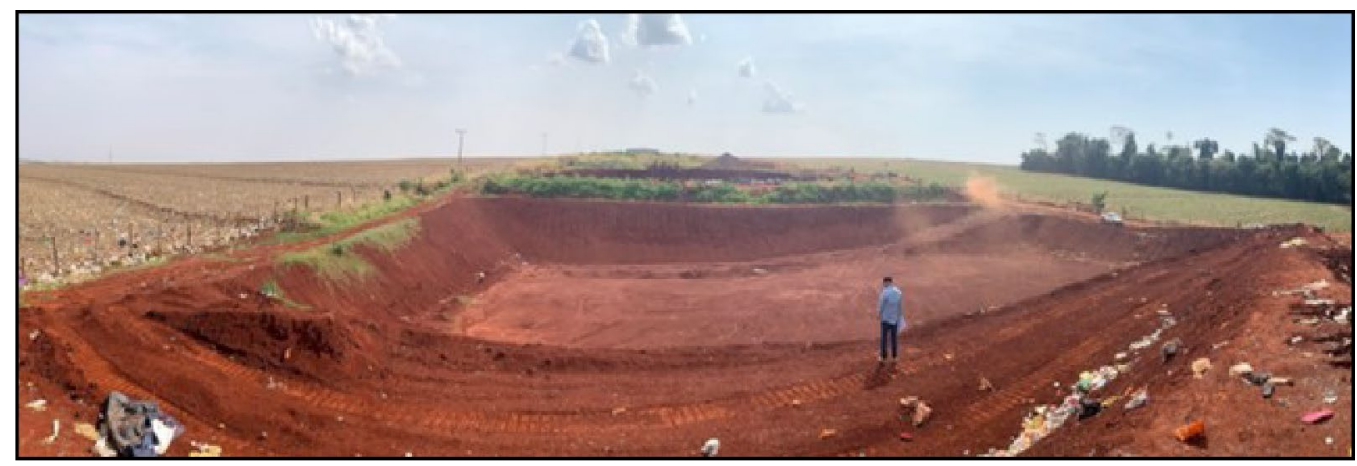

Figure 17. Vala 2

Conforme aborda Reichert and Projeto (2007), em situações que não houver uma disponibilidade contínua de um trator deesteira, pode-se utilizar máquinas de menor custo, como retroescavadeiras, que podem executar trabalhos de escavação e compactação, porém com uma menor eficiência.

\section{CONSLUSÃO}

O presente estudo permitiu concluir que, por meio das visitas in loco e com o auxílio do método IQR, foi possível diagnosticar a situação do local de disposição final de resíduos sólidos do município de Paiçandu (PR). Além disso, foram propostas regularizações e melhorias para tal sistema.

Com as visitas in loco, foram identificadas características de irregularidades no local. A vala existente possui células sobrepostas além do permitido, uma vez que a vala já está saturada. A infraestrutura existente não contempla drenagem de gases e possui um sistema de drenagem de chorume ineficaz. O local não possui drenagem pluvial.

Um local de disposição final de resíduos sólidos, geralmente emite um mau cheiro, portanto, é necessário um fechamento ao redor de vegetação, com o intuito de impossibilitar que esse odor chegue aos arredores, além de auxiliar no isolamento visual e não permitir sacos plásticos nos lotes vizinhos, porém o sistema atual não possui um isolamento adequado.

O sistema de impermeabilização usado para proteger o solo é por meio da implantação de uma manta de PEAD, geralmente com espessura de $2 \mathrm{~mm}$. Assim também é impermeabilizada a lagoa de tratamento de chorume, contudo, a lagoa existente está danificada, permitindo o risco de contaminação no solo.

Quanto à operação, a maioria dos maquinários usados são terceirizados, o que gera um custo considerável para a prefeitura. Além disso, o local não possui funcionários suficientes para uma operação adequada, deixando a desejar nesse quesito. Vale ressaltar a importância da capacitação dos mesmos para exercer suas respectivas funções, pois uma má operação pode levar o sistema à decadência.

O IQR foi uma ferramenta de extrema importância para avaliar a área e todo o sistema de disposição final de resíduos sólidos, pois lista vários pontos que necessitam ser considerados num sistema de disposição final de resíduos, desde aspectos relativos à área do local, infraestrutura, características do solo, recursos hídricos, até a operação. Neste mesmo IQR,concluiu-se que o local 
apresenta condições inadequadas, uma vez que a nota foi 5,4, portanto, menor que 7,0, que seria o mínimo para se enquadrar no quesito "condições adequadas".

Diante das informações obtidas, foi possível desenvolver propostas de readequações e melhorias possíveis de serem realizadas e da maneira correta de ser executada, com o propósito de transformar o sistema de disposição final de resíduos existente num verdadeiro aterro sanitário, com características e operação de tal.

Por fim, recomenda-se para trabalhos futuros que se estude e analise o sistema de disposição final de resíduos sólidos nos municípios. Também, para o dimensionamento de futuras valas e manutenções, aprofundar-se numa avaliação do projeto de engenharia do aterro sanitário, bem como uma avaliação de compatibilidade entre projeto e implantação, além da obtenção de uma geração per capita do município por meio de um estudo de caracterização gravimétrica.

\section{Referências}

ALBERTE, E.P.V.; CARNEIRO, A.P.; KAN, L. Recuperação de áreas degradadas por disposição de Resíduos Sólidos Urbanos, Feira de Santana, ano 3, n. 5, junho 2005. Disponível em: http://waste.com.br/textos/20-062005_11-50-14_linkan.pdf. Acesso em: 5 de jun. 2020.

ALBERTIN, R.M.; MORAES, E.; DE ANGELIS NETO, G.; DE ANGELIS, B.L.D.; SCHMIDT, A.P. Avaliação da disposição final de resíduos sólidos urbanos no município de Cianorte, Paraná. Tecnológica, Santa Cruz do Sul, ano 2, v. 15, p. 53-61, 4 jun. 2011. Disponível em:

https://online.unisc.br/seer/index.php/tecnologica/article/view/1893/1602. Acesso em: 25 de out. 2020.

ALMEIDA, D.S.; Recuperação Ambiental Da Mata Atlântica, Ilhéus, ed. 3, 2016. DOI 10.7476/9788574554402. Disponível em: https://static.scielo.org/scielobooks/8xvf4/pdf/almeida-9788574554402.pdf. Acesso em: 6 de jun. 2020.

ANDRADE, S.F. Aplicação da Técnica de Recirculação de Chorume em Aterros Tropicais - Estudo de Caso do Aterro Sanitário Metropolitano Centro (ASMC). 2014. 173 p. Dissertação em Engenharia Ambiental Urbana Universidade Federal da Bahia, Salvador, 2014. Disponível em: https://www.tratamentodeagua.com.br/wpcontent/uploads/2016/08/Aplica\%C3\%A7\%C3\%A3o-da-t\%C3\%A9cnica-de-recircula\%C3\%A7\%C3\%A3o-dechorume-em-aterros-tropicais- $\% \mathrm{E} 2 \% 80 \% 93$-estudo-de-caso-do-aterro-sanit $\% \mathrm{C} 3 \% \mathrm{~A} 1$ rio-metropolitano-centroASMC.pdf. Acesso em: 15 de jun. 2020.

ABNT - ASSOCIAÇÃO BRASILEIRA DE NORMAS TÉCNICAS. NBR 10.004: Resíduos Sólidos - Classificação. Rio de Janeiro, 2004.

NR 6 - Norma regulamentadora 6 - equipamento de proteção individual. Rio de Janeiro, 2006.

. NBR 13.221: Transporte terrestre de resíduos. Rio de Janeiro, 2003.

. NBR 13.896: Aterros de resíduos não perigosos. Rio de Janeiro, 1997.

. NBR 15.849: Aterros Sanitários de pequeno porte. Rio de Janeiro, 2010.

. NBR 15.935: Investigações ambientais - Aplicação de métodos geofísicos. Rio de Janeiro, 2011.

. NBR 8.419: Apresentação de projetos de aterros sanitários de resíduos sólidos urbanos. Rio de Janeiro, 1992.

. NBR 9.603: Sondagem a trado - Procedimento. Rio de Janeiro, 2015.

. NBR 13.221. Transporte terrestre de produtos perigosos resíduos. Rio de Janeiro, 2021.

ABRELPE - Associação Brasileira de Empresas de Limpeza Pública e Resíduos Especiais. Panorama dos resíduos sólidos no Brasil 2018/2019. São Paulo: 2019. Anual. Disponível em: https://abrelpe.org.br/panorama/. Acesso em: 25 de maio. 2020.

BARROS, R.M. Tratado Sobre Resíduos Sólidos. Gestão, Uso e Sustentabilidade. 1. ed. Minas Gerais: Interciência, janeiro 2016. 374 p.

BECHARA, F.C. Unidades Demonstrativas de Restauração Ecológica através de Técnicas Nucleadoras: Floresta 
Estacional Semidecidual, Cerrado e Restinga. 2006. 248 p. Tese (Doutorado em Recursos Florestais) - Universidade de São Paulo, Piracicaba, 2006. Disponível em: https://www.teses.usp.br/teses/disponiveis/11/11150/tde-22082006145733/publico/FernandoBechara.pdf. Acesso em: 15 de jun. 2020.

BOGDAN, R.C. Investigação Qualitativa em Educação: Uma Introdução à Teoria e aos Métodos. Portugal: Porto Editora, 1994. $336 \mathrm{p}$.

BRASIL. Decreto no 7.405, de 23 de dezembro de 2010. Institui o Programa Pró-Catador, denomina Comitê Interministerial para Inclusão Social e Econômica dos Catadores de Materiais Reutilizáveis e Recicláveis o Comitê Interministerial da Inclusão Social de Catadores de Lixo criado pelo Decreto de 11set.2003, dispõe sobre sua organização e funcionamento, e dá outras providências. Brasília, DF: Presidência da República, 2010. Disponível em: http://www.planalto.gov.br/ccivil_03/_ato2007-2010/2010/decreto/d7405.htm. Acesso em: 20 de jun. 2020.

LEI N ${ }^{0}$ 12.651, de 25 de maio de 2012. Dispõe sobre a proteção da vegetação nativa; altera as Leis $\mathrm{n}^{0} \mathrm{~s}$ 6.938, de 31 de agosto de 1981, 9.393, de 19 de dezembro de 1996, e 11.428, de 22 de dezembro de 2006; revoga as Leis n ${ }^{\circ}$ s 4.771, de 15 de setembro de 1965, e 7.754, de 14 de abril de 1989, e a Medida Provisória n ${ }^{\circ} 2.166-67$, de 24 de agosto de 2001; e dá outras providências. Disponível em: http://www.planalto.gov.br/ccivil_03/_ato20112014/2012/lei/112651.htm. Acesso em: 7 de out. 2021.

Lei $\mathbf{n}^{\mathbf{0}}$ 12.305, de 2 de agosto de 2010. Institui a Política Nacional de Resíduos Sólidos; altera a Lei no 9.605, de 12fev.1998; e dá outras providências. [S. l.], 2.ago.2010. Disponível em:

http://www.planalto.gov.br/ccivil_03/_ato2007-2010/2010/lei/112305.htm. Acesso em: 20 de mar. 2020.

CASTILHOS JUNIOR, A.B. Alternativas de Disposição de Resíduos Sólidos Urbanos para Pequenas

Comunidades. 1. ed. Florianópolis: [s. n.], 2002. 92 p. ISBN 85-86552-35-6. Disponível em: https://www.finep.gov.br/images/apoio-e-financiamento/historico-de-programas/prosab/livrocompletofinal.pdf. Acesso em: 10 de abr. 2020.

CETESB. Restauração ecológica: sistemas de nucleação. São Paulo: [s. n.], 2011. 63 p. ISBN 978-85-86624-73-5. Disponível em: https://sigam.ambiente.sp.gov.br/sigam3/Repositorio/222/Documentos/Nucleacao.pdf. Acesso em: 5 de jun. 2020.

Inventário Estadual de Resíduos Sólidos Urbanos. São Paulo: 2019. 74 pag. ISBN 0103-4103. Disponível em:https://cetesb.sp.gov.br/residuossolidos/wp-content/uploads/sites/26/2020/10/Inventario-Estadual-de-ResiduosSolidos-Urbanos-2019.pdf. Acesso em: 7 de out. 2021.

Manual de Gerenciamento de Áreas Contaminadas. 2. ed. São Paulo: [s. n.], 2001. 389 p. Disponível em: http://200.144.0.248/DOWNLOAD/CERTIFICADOS/AC2019/Manual\%20Cetesb\%20Completo.pdf. Acesso em: 20 de maio. 2020.

CHRISTENSEN, T.H.; KORINEK, P.; ALBRECHTSEN, H. Biogeochemistry of landfill leachate plumes. Biogeochemistry of landfill leachate plumes, Dinamarca, p. 659-718, 2001. Disponível em: https://www.academia.edu/13183107/Biogeochemistry_of_landfill_leachate_plumes. Acesso em: 11 de abr. 2020.

COLMANETTI, J.P. Estudos sobre a aplicação de geomembranas na impermeabilização da face de montante de barragens de enrocamento. Tese. UnB. Disponível em: file://C:/Users/asus/Downloads/2006_Janaina\%20Prov\%C3\%A1sio\%20Colmanetti.pdf. Acesso em: 7 de out. 2021.

CONAMA. Resolução $\mathbf{n}^{\mathbf{0}} \mathbf{4 2 0}$, de 28 de dezembro de 2009. Dispõe sobre critérios e valores orientadores de qualidade do solo quanto à presença de substâncias químicas e estabelece diretrizes para o gerenciamento ambiental de áreas contaminadas por essas substâncias em decorrência de atividades antrópicas. 28.dez.2009. Disponível em: http://www2.mma.gov.br/port/conama/legiabre.cfm?codlegi=620. Acesso em: 26 de abr. 2020.

COPEL. Manual para Gerenciamento de Resíduos Sólidos. Curitiba: [s. n.], 2001. 77 p. Disponível em: https://www.copel.com/hpcopel/root/sitearquivos2.nsf/arquivos/manual_gerenciamento_residuos_solidos/\$FILE/Man ual\%20para\%20Gerenciamento\%20de\%20Res\%C3\%ADduos\%20v1.88.pdf. Acesso em: 20 de maio. 2020.

CREA (org.). Guia para elaboração de projetos de aterros sanitários para resíduos sólidos urbanos. [S. l.: s. $n$.], 2009. 63 p. v. 2. Disponível em: https://www.crea-pr.org.br/ws/wp- 
content/uploads/2016/12/Publica\%C3\%A7\%C3\%B5es-Tem\%C3\%A1ticas-Guia-para-Elabora\%C3\%A7\%C3\%A3ode-Projetos-de-Aterros-Sanit\%C3\%A1 rios-para-Res\%C3\%ADduos-S\%C3\%B3lidos-Urbanos-Volume-II.pdf. Acesso em: 10 de jun. 2020 .

EMBRAPA - Centro Nacional de Pesquisa de Solos. Mapa de solos do Estado do Paraná. Rio de Janeiro. EMBRAPA/CNPS, 2007. (Série Documentos, 96). CD ROM

FUNASA. Assessoria de Comunicação e Educação em Saúde (ed.). Manual de Saneamento. 3. ed. rev. Brasília: [s. n.], 2006. 407 p. ISBN 85-7346-045-8.

GIL, A.C. Como Elaborar Projetos de Pesquisa. 4. ed. São Paulo: Atlas, 2012. 175 p. ISBN 85-224-3169-8. Disponível em: https:/files.cercomp.ufg.br/weby/up/150/o/Anexo_C1_como_elaborar_projeto_de_pesquisa__antonio_carlos_gil.pdf. Acesso em: 15 de jun. 2020.

GOOGLE. Googlemaps. [S. l.], 2020. Disponível em: https:/www.google.com.br/maps/preview. Acesso em: 20 de jun. 2020.

GRASSLER, E.; PIZOL, M.A.L.; MORELLATO, L.P.C. Polinização e dispersão de sementes em Myrtaceae do Brasil. Braz. J. Bot. v. 29 n. 4, p. 509-530, out.-dez., 2006. DOI https://oi.org/10.1590/S0100-84042006000400002.

GUEVARA, S.; LABORDE, J. 1993. Monitoring seed dispersal at isolated standing trees in tropical pastures: consequences for local species availability. Vegetation 107: 319-338.

IBAMA. Instrução Normativa no 04, de 13 de abril de 2011. Procedimentos para elaboração de Projeto de Recuperação de Área Degradada - PRAD ou Área Alterada, para fins de cumprimento da legislação ambiental: Estabelecer procedimentos para elaboração de Projeto de Recuperação de Área Degradada - PRAD ou Área Alterada, para fins de cumprimento da legislação ambiental, bem como dos Termos de Referência constantes dos Anexos I e II desta Instrução Normativa, [S. l.], 13 abr. 2011. Disponível em: https://docplayer.com.br/54136288-Instrucaonormativa-no-4-de-13-de-abril-de-2011.html. Acesso em: 21 de jun. 2020.

IBGE. Amparo. População. Rio de Janeiro:IBGE, 2010. Disponível em: https:/cidades.ibge.gov.br/brasil/pr/paicandu/panorama. Acesso em: 20 de jun. 2020.

Amparo. Território e Ambiente. Rio de Janeiro:IBGE, 2019. Disponível em: https://cidades.ibge.gov.br/brasil/pr/paicandu/panorama. Acesso em: 20 de jun. 2020.

MATTAR, F.N. Pesquisa de Marketing. 3. ed. São Paulo: Atlas, 2001. 488 p. ISBN 9788535259216.

MMA. Coleta seletiva: o que é coleta seletiva? [S. l.], [2020]. Disponível em: https://www.mma.gov.br/cidadessustentaveis/residuos-solidos/catadores-de-materiais-reciclaveis/reciclagem-e-reaproveitamento. Acesso em: 27 de maio. 2020 .

Planos de gestão de resíduos sólidos: manual de orientação. Brasília: [s. n.], 2012. 156 p. ISBN 978-8599093-21-4. Disponível em:

https://www.mma.gov.br/estruturas/182/_arquivos/manual_de_residuos_solidos3003_182.pdf. Acesso em: 26 de maio. 2020 .

Roteiro de apresentação para Plano de Recuperação de Área Degradada (PRAD) terrestre. 3. ed. [S. l.:s.n.], 2013. 13 p. Disponível em:

https://www.icmbio.gov.br/parnaserradabocaina/images/stories/o_que_fazemos/gestao_e_manejo/Roteiro_PRAD_ver sao_3.pdf. Acesso em: 7 de jun. 2020.

MONTEIRO, J.H.P.; ZVEIBIL, V.Z.; FIGUEIREDO, C.E.M. Manual de gerenciamento integrado de resíduos sólidos. Rio de Janeiro: [s. n.], 2001. 204 p.

MTX CONSTRUTORA LTDA (org.). Estudo de impacto ambiental (EIA): aterro industrial - resíduos classes I e II, aterro de resíduos da construção civil - resíduos classe A. Piraí do Sul: [s. n.], 2017. 428 p. v. 1. Disponível em: http://www.iap.pr.gov.br/arquivos/File/2017_EIA_RIMA/EIA_MTX.pdf. Acesso em: 26 de out. 2020.

ODA, S. Terraplenagem. Universidade Estadual de Maringá. Departamento de Engenharia Civil. Disponível em: http://www.dec.uem.br/docentes/soda/proj8A_tpg.pdf. Acesso em: 6 de out. 2021. 
PARANÁ. Portaria n⿳2 259, de 26 de novembro de 2014. Aprova e estabelece os critérios e exigências para a apresentação do AUTOMONITORAMENTO AMBIENTAL DE ATERROS SANITÁRIOS no Paraná e determina seu cumprimento. [S. l.], 2014. Disponível em: https://www.legisweb.com.br/legislacao/?id=277837. Acesso em: 20 de maio. 2020.

REICHERT, G.A. Projeto, operação e monitoramento de aterros sanitários. Porto Alegre: [s. n.], 2007.114 p. Disponível em: https://pt.scribd.com/doc/282473498/Manual-Aterro-Sanitario-2007-Geraldo-Reichert-pdf. Acesso em: 10 de abr. 2020.

REIS, A.; BECHARA, F.C.; ESPÍNDOLA, M.B.; VIEIRA, N.K.; SOUZA, L.P. Restauração de áreas degradadas: a nucleação como base para incrementar os processos sucessionais. Natureza e Conservação, [S. l.], v. 1, n. 1, p. 28 36, 1 abr. 2003. Disponível em: http://www.lerf.esalq.usp.br/divulgacao/recomendados/artigos/reis2003.pdf. Acesso em: 2 de jun. 2020.

RODRIGUES, W.N. Recuperação de áreas degradadas. [S. l.: s. n.], [20--]. cap. 2, p. 22-35. Disponível em: https://phytotechnics.com/content/files/livro02-01.pdf. Acesso em: 13 de jun. 2020.

ROSADO, A.M. Avaliação da condição do aterro municipal de Paiçandu/PR por meio do método IQR. 2018. 17 p. Trabalho de conclusão de curso (Graduação em Engenharia Ambiental) - Centro Universitário de Maringá, Maringá, 2018.

SANTAELLA, S.T.; BRITO, A.E.R.M.; COSTA, F.A.P.; CASTILHO, N.M.; DE MIO, G.P.; FERREIRA FILHO, E.; LEITÃO, R.C.; SALEK, J.M. Resíduos sólidos e a atual política ambiental brasileira. Fortaleza: [s. $n$.], 2014. 231 p. v. 7. ISBN 978-85-420-0326-0. Disponível em:

https://www.researchgate.net/publication/273132019_Residuos_solidos_e_a_atual_politica_ambiental_brasileira. Acesso em: 26 de mai. 2020.

SEBRAE-MS. Gestão de resíduos sólidos: uma oportunidade para o desenvolvimento municipal e para as micro e pequenas empresas. São Paulo: [s. n.], 2012. 31 p. ISBN 978-85-62678-01-1. Disponível em:

http://extranet2.pr.sebrae.com.br/portal/sustentabilidade/Gest $\%$ C3\%A3o\%20de\%20Res\%C3\%ADduos\%20S\%C3\%B 3lidos.pdf. Acesso em: 2 de jun. 2020.

SNSA - SECRETARIA NACIONAL DE SANEAMENTO AMBIENTAL (org.). Resíduos sólidos: projeto, operação e monitoramento de aterros sanitários. Belo Horizonte: [s. n.], 2008. 120 p.

SILVA FILHO, S.R. Proposta de Modelo de Aterro Sanitário Simplificado para Municípios de Pequeno Porte. 2017. 95 p. Trabalho de conclusão de curso (Graduação em Engenharia Civil) - Universidade Federal da Paraíba, João Pessoa, 2017. Disponível em: http://ct.ufpb.br/ccec/contents/documentos/tccs/2016.2/proposta-de-modelo-deaterro-sanitario-simplificado-para-municipios-de-pequeno-porte.pdf. Acesso em: 12 de abr. 2020.

SILVA, A.J.H. Metodologia da pesquisa: conceitos gerais. [S. l.: s. n.], 2014. 56 p. Disponível em: http://repositorio.unicentro.br:8080/jspui/bitstream/123456789/841/1/Metodologia-da-pesquisa-cient\%c3\%adficaconceitos-gerais.pdf. Acesso em: 19 de jun. 2020.

SZIGETHY, L.; ANTENOR, S. Resíduos sólidos urbanos no Brasil: desafios tecnológicos, políticos e econômicos. Disponivel em: https://www.ipea.gov.br/cts/pt/central-de-conteudo/artigos/artigos/217-residuos-solidos-urbanos-nobrasil-desafios-tecnologicos-politicos-e-economicos. Acesso em: 6 de out. 2021.

TOPOGRAPHIC-MAP. Mapas topográficos. [S. l.], 2020. Disponível em: https://pt-br.topographicmap.com/maps/gwd6/Pai\%C3\%A7andu/. Acesso em: 20 de jun. 2020. 